\title{
The influence of ventilated façade on sound insulation properties of envelope walls
}

\author{
Zuzana Fišarová ${ }^{1}$, Lubor Kalousek ${ }^{1, *}$, Michal Frank ${ }^{2}$, and Roman Brzoň ${ }^{1}$ \\ ${ }^{1}$ Brno University of Technology, Faculty of Civil Engineering, Veveři 95, 60200 Brno, Czech \\ Republic \\ ${ }^{2}$ Research Institute for Building Materials, Hněvkovského 30/65, 61700 Brno, Czech Republic
}

\begin{abstract}
Presented article deals with sound insulation properties of timber structures' envelope walls. Particularly, the influence of heavy board ventilated façade on laboratory airborne sound insulation $\mathrm{R}$ and $\mathrm{R}_{\mathrm{w}}$ in $\mathrm{dB}$ was studied. The installation method and gaps between façade boards can cause building defects originating in overrating the influence of ventilated cladding on envelope wall acoustic parameters. Real constructions were built for the experimental purposes and measurements, one with gaps between boards and one with simply eliminated gaps for mutual comparison. The results obtained were processed to make tables and graphs and to derive recommendations for the design of this type of constructions involving the general installation method of façade boards. Detailed results are depicted in conclusions.
\end{abstract}

\section{Introduction}

Due to growing rate of timber structure buildings in the Czech market, the issue of protecting the inner environment and its inhabitants against excessive noise slowly emerges. The issue of insufficient sound insulation of the envelope wall was frequently neglected especially in small buildings for housing. A significant change came with amendment of Act No. 258/2000 Coll., on public health protection, and following amendment of some related laws. This amendment reflects particularly increasing requirements on protection against noise adverse effects and in this respect fundamentally toughens the whole building approval process. The amendment is applied on residential building as well as on educational, healthcare and similar buildings.

The presented experiment was conducted with timber structures' envelope wall. However, the findings on the influence of the ventilated façade are generally valid also for other types of walls, e.g. brick walls or aerated concrete block walls.

\footnotetext{
* Corresponding author: kalousek.1@fce.vutbr.cz
} 


\section{General requirements on sound insulation of envelope walls}

General requirements on sound insulation of envelope walls and their parts are given in ČSN 73 0532/2010 - Acoustics - Protection against noise in buildings and evaluation of acoustic properties of building elements - Requirements, [1].

Whether a real finished construction meets the requirements is verified by an experiment on building site according to ČSN EN ISO 140-5, [2].

In designing phase, engineers rely on calculations and values given by producers or suppliers of the envelope construction or its parts.

\section{Sound insulation defects of envelope walls}

As mentioned in the introduction, errors can occur in design and execution of the envelope walls. One of the most significant errors is underestimating the influence of specific insulation material on the sound insulation properties of the resulting structure. This topic was by authors described in detail in [3], where the comparison of acoustic properties of envelope walls before and after ETICS application is the main topic. Among other a significant decrease of sound reduction index R from approx. 180 to $600 \mathrm{~Hz}$ due to some insulation materials was analyzed in this publication.

Another frequently occurring phenomenon is the absence of plaster on the outside of envelope wall due to presence of thermal insulation layer. Designers mistakenly think that a brick or a block has the same sound insulation properties with one sided plaster and with both sided plaster.

Last but not least mistake is overestimating the influence of outer ventilated cladding which can easily occur especially with heavy facade boards. This issue is the main topic of this article and currently available data are widened by measurements on real constructions.

\section{Experiment description}

The prime aim of the experiment was a general widening of knowledge on sound insulation properties of building envelope construction made of D3D system according to utility model No. 15073 U1, [4]. Mainly the influence of different contact thermal insulation materials was evaluated as described in [5] and followingly, the benefit of heavy facade boards was analyzed. Through the whole project, numerous structures were examined. All laboratory sound insulation measurements were conducted according to valid methodics in acoustic echo chamber of the Institute of Physical Engineering, laboratory accredited by ČIA under No. 1016, Brno University of Technology.

\section{Specification of measured structures}

Three basic groups of tests were conducted gradually during the construction. The first group is represented by measurements of basic D3D construction insulated by $2 \times 100 \mathrm{~mm}$ Steico Flex and covered by Egger boards and with external ventilated cladding made of heavy CEMVIN facade boards. For detailed description see Fig. 1. 
WINDPROOF MEMBRANE - JUTADACH 135 JOINTS OVERLAPPED BY $100 \mathrm{~mm}$

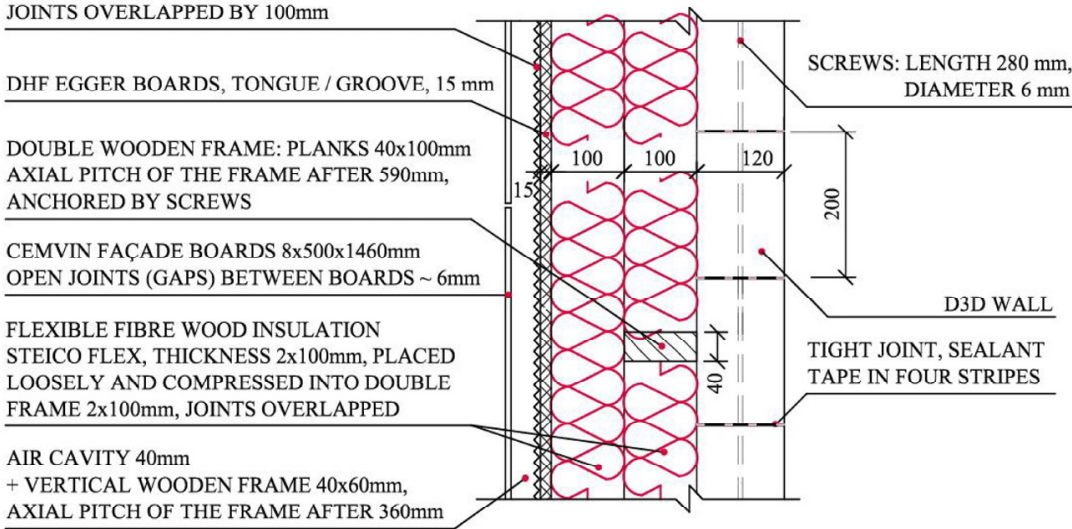

NOTE:

PERIMETER OF THE SAMPLE WAS SEALED BY A STRIP

OF MINERAL WOOL, THICKNESS APPROX. 10mm

AND FINISHED BY ACRYLIC SEALANT ON BOTH SIDES,

EACH LAYER WAS SEALED SEPARATELY (I.E. A TOTAL 6 LAYERS AROUND THE PERIMETER),

FRAMES 40x100mm WERE SEALED BY INSULATION AND ACRYLIC SEALANT,

PERIMETER OF WINDPROOF MEMBRANE COMPLETED BY SEALANT,

WOODEN FRAME 40x60mm UNSEALED - ENDED APPROX $30 \mathrm{~mm}$ FROM THE EDGE,

PERIMETER OF CEMVIN FACADE BOARDS SEALED BY INSULATION AND FINISHED BY ACRYLIC

SEALANT, JOINTS BETWEEN BOARDS APPROX 6mm - OPEN GAPS

Fig. 1. First measurement group - basic structure with Steico Flex thermal insulation and external ventilated cladding.

For the second group of measurements, Steico Flex insulation was replaced by ISOVER UNI, all other parts remained unchanged (see Fig. 2).

WINDPROOF MEMBRANE - JUTADACH 135

JOINTS OVERLAPPED BY $100 \mathrm{~mm}$

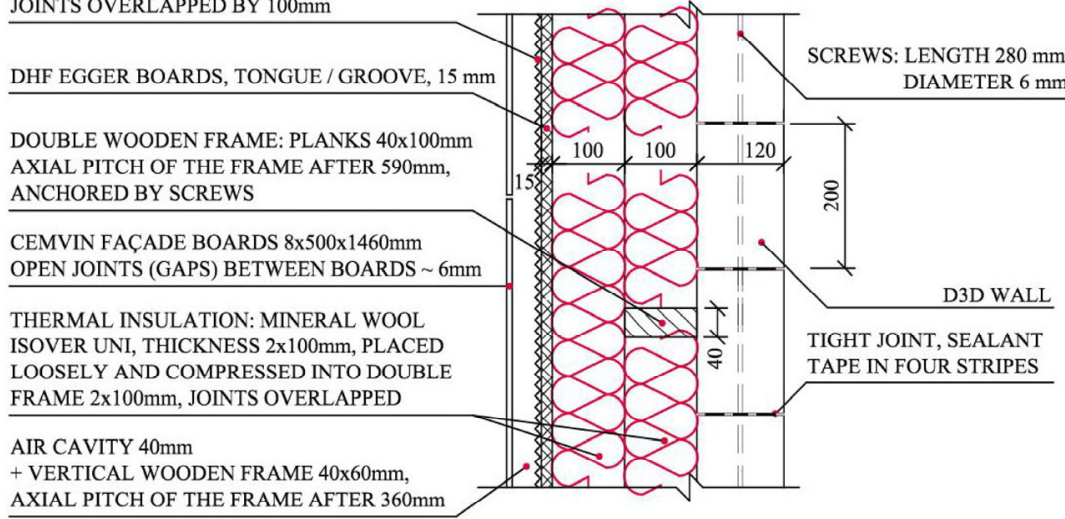

NOTE:

PERIMETER OF THE SAMPLE WAS SEALED BY A STRIP

OF MINERAL WOOL, THICKNESS APPROX. 10mm

AND FINISHED BY ACRYLIC SEALANT ON BOTH SIDES,

EACH LAYER WAS SEALED SEPARATELY (I.E. A TOTAL 6 LAYERS AROUND THE PERIMETER),

FRAMES 40x100mm WERE SEALED BY INSULATION AND ACRYLIC SEALANT,

PERIMETER OF WINDPROOF MEMBRANE COMPLETED BY SEALANT,

WOODEN FRAME 40x60mm UNSEALED - ENDED APPROX $30 \mathrm{~mm}$ FROM THE EDGE,

PERIMETER OF CEMVIN FAÇADE BOARDS SEALED BY INSULATION AND FINISHED BY ACRYLIC

SEALANT, JOINTS BETWEEN BOARDS APPROX 6mm - OPEN GAPS

Fig. 2. Second group of measurements - basic structure with ISOVER UNI thermal insulation and external ventilated cladding. 
For the third group of measurements, a sample with simple external cladding gap elimination was constructed and the influence on sound insulation was examined. The gaps, i.e. free joints between façade boards, on existing structure measured in previous step were precisely sealed and covered with an aluminium tape as seen in Fig. 3 and 4. The other parts of previous composition remained unchanged.

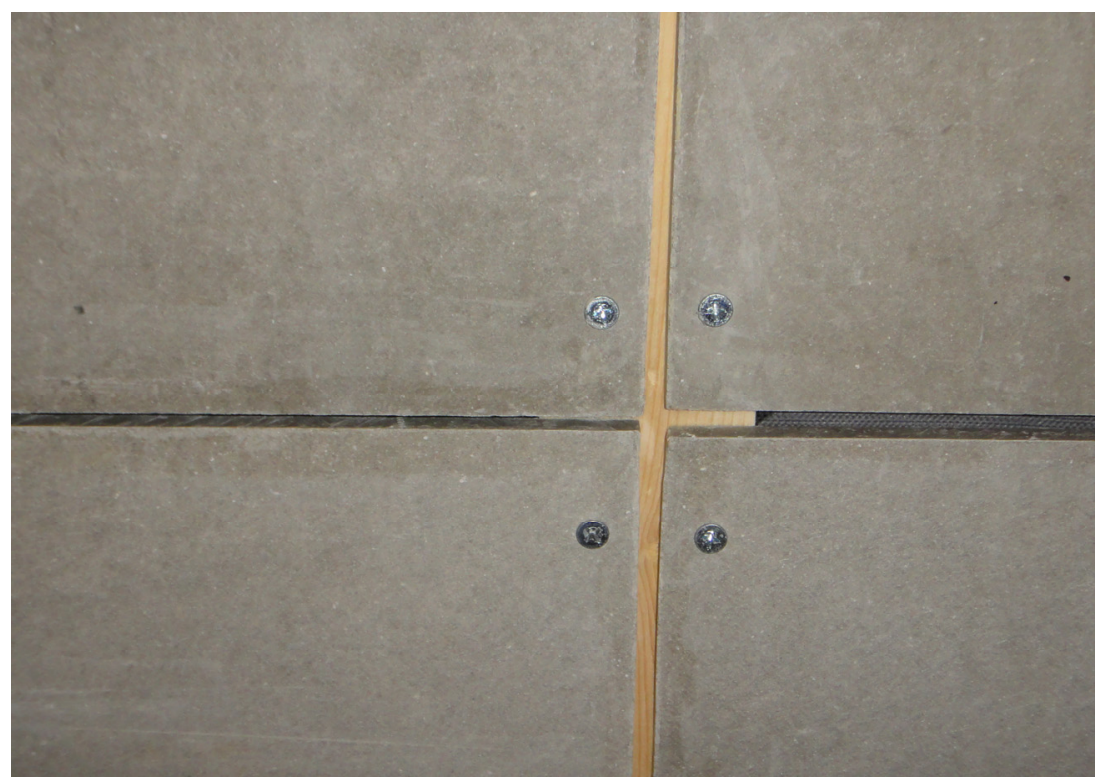

Fig. 3. Detail of gaps between CEMVIN boards of external ventilated cladding.

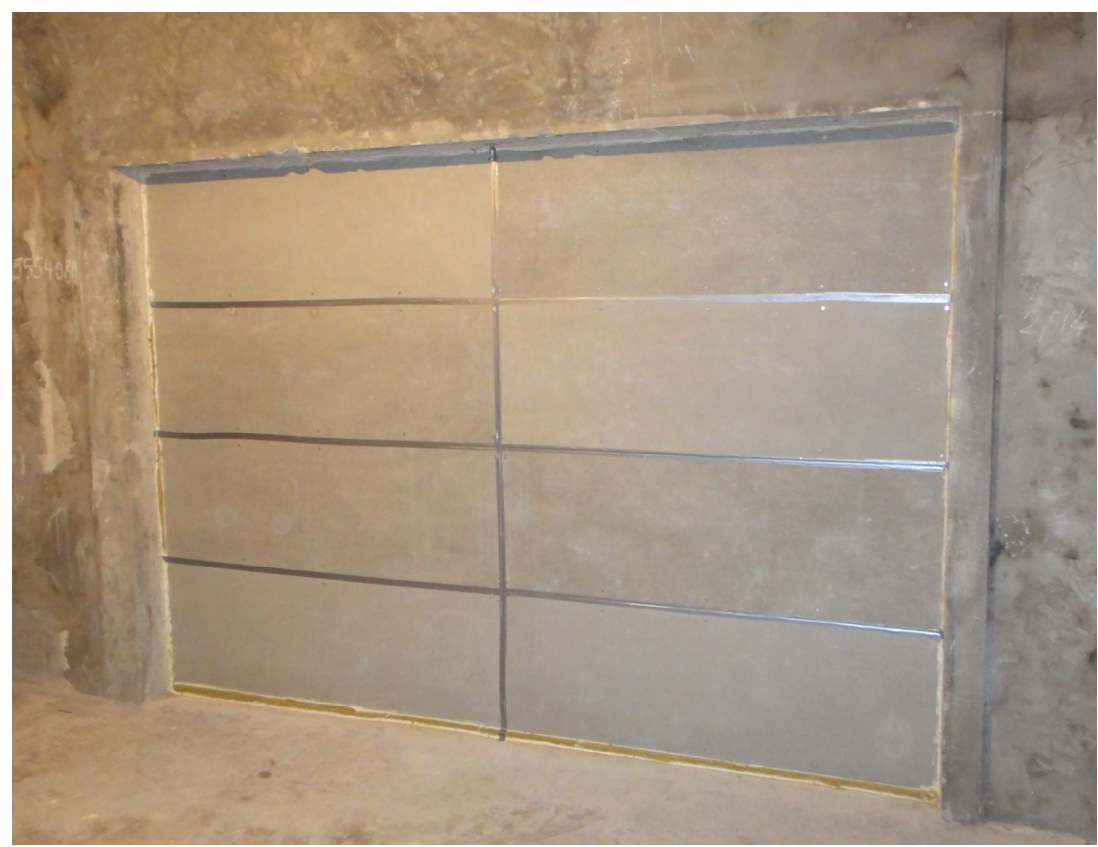

Fig. 4. View of the external cladding, gaps are sealed and covered by aluminium tape. 


\section{Results of measurements}

Graph 1. The first group of measurements - the influence of the external ventilated cladding on sound insulation properties of structure with Steico Flex thermal insulation.

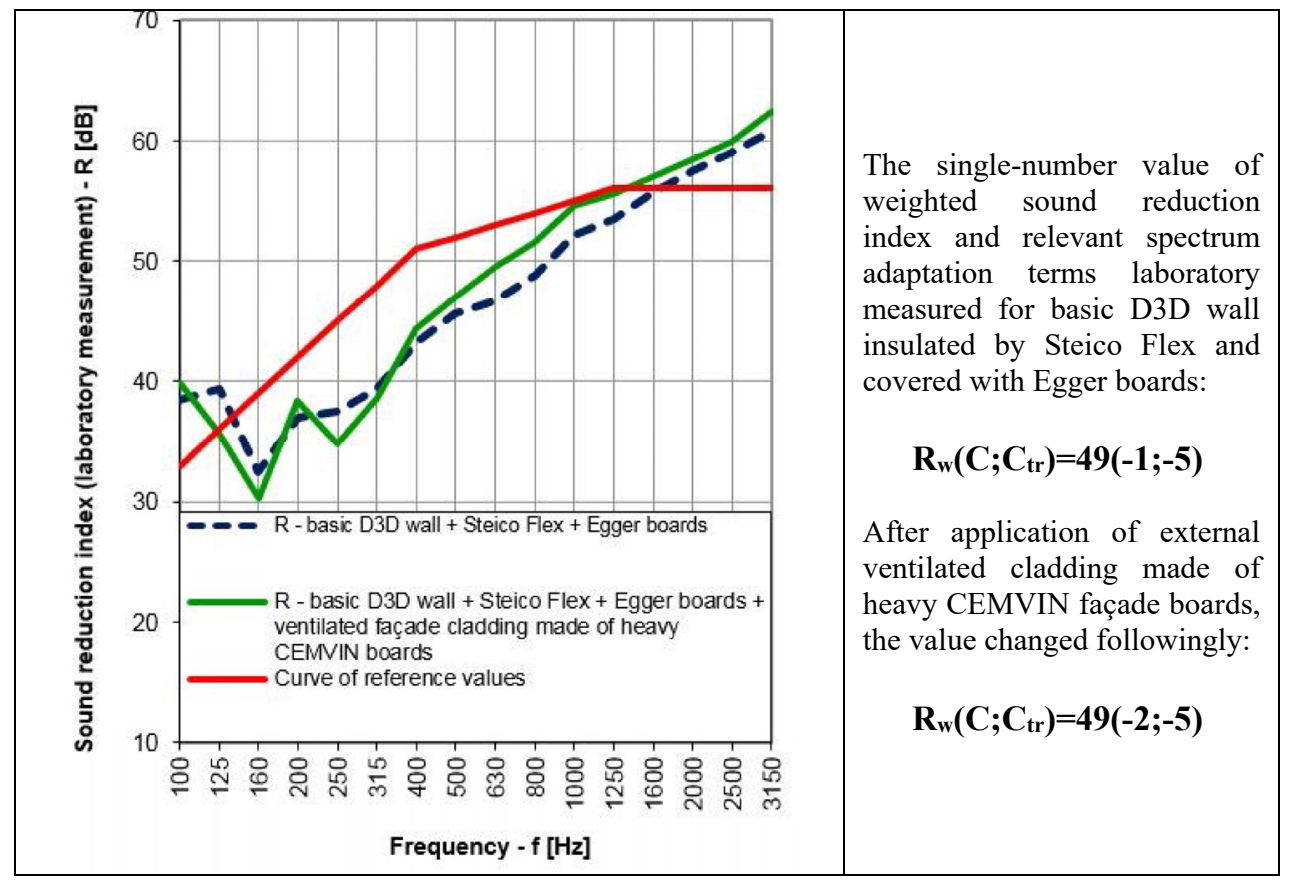

Graph 2. The second group of measurements - the influence of the external ventilated cladding on sound insulation properties of structure with ISOVER UNI thermal insulation.

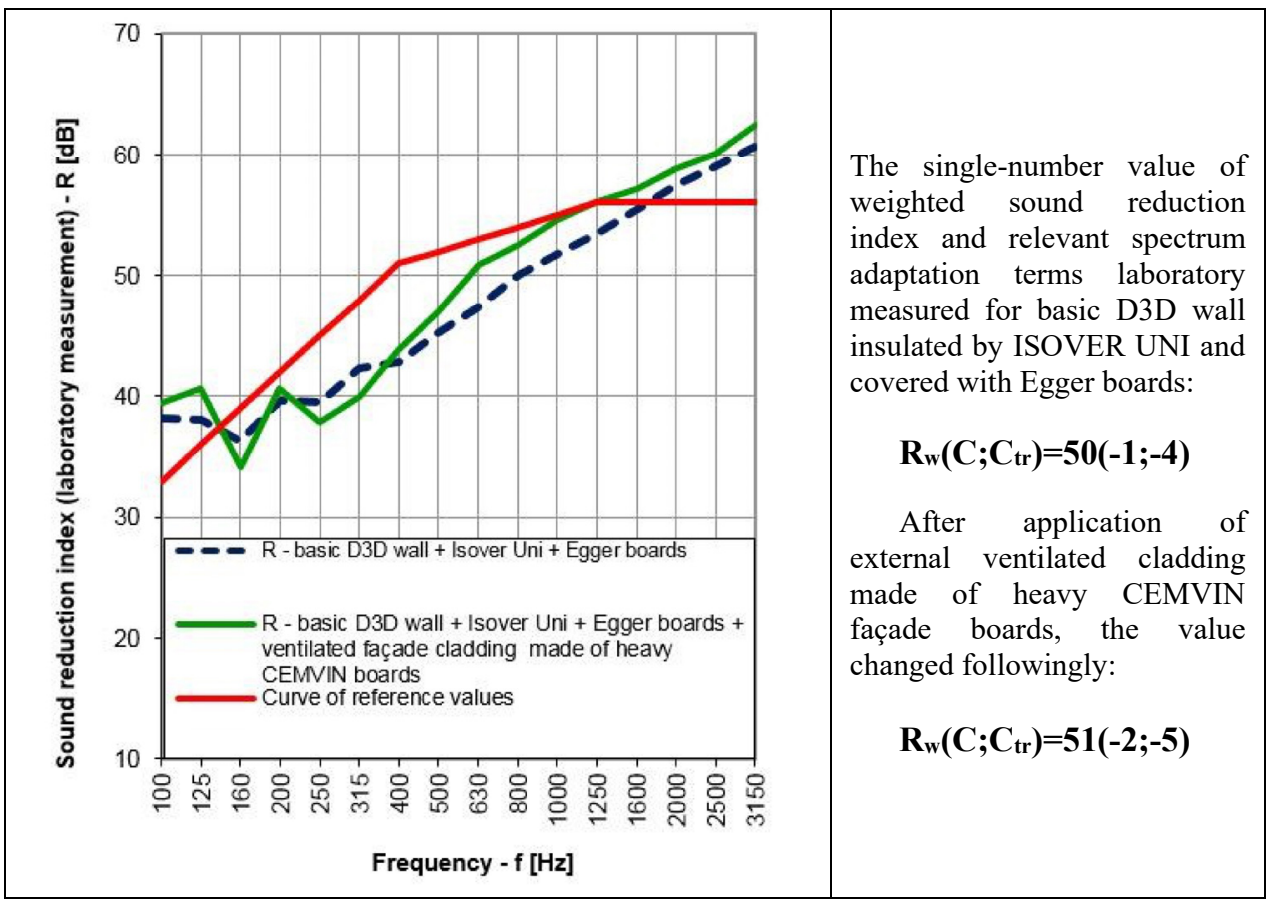


Graph 3. The third group of measurements - the influence of sealed external cladding gaps on sound insulation properties of structure with ISOVER UNI thermal insulation.

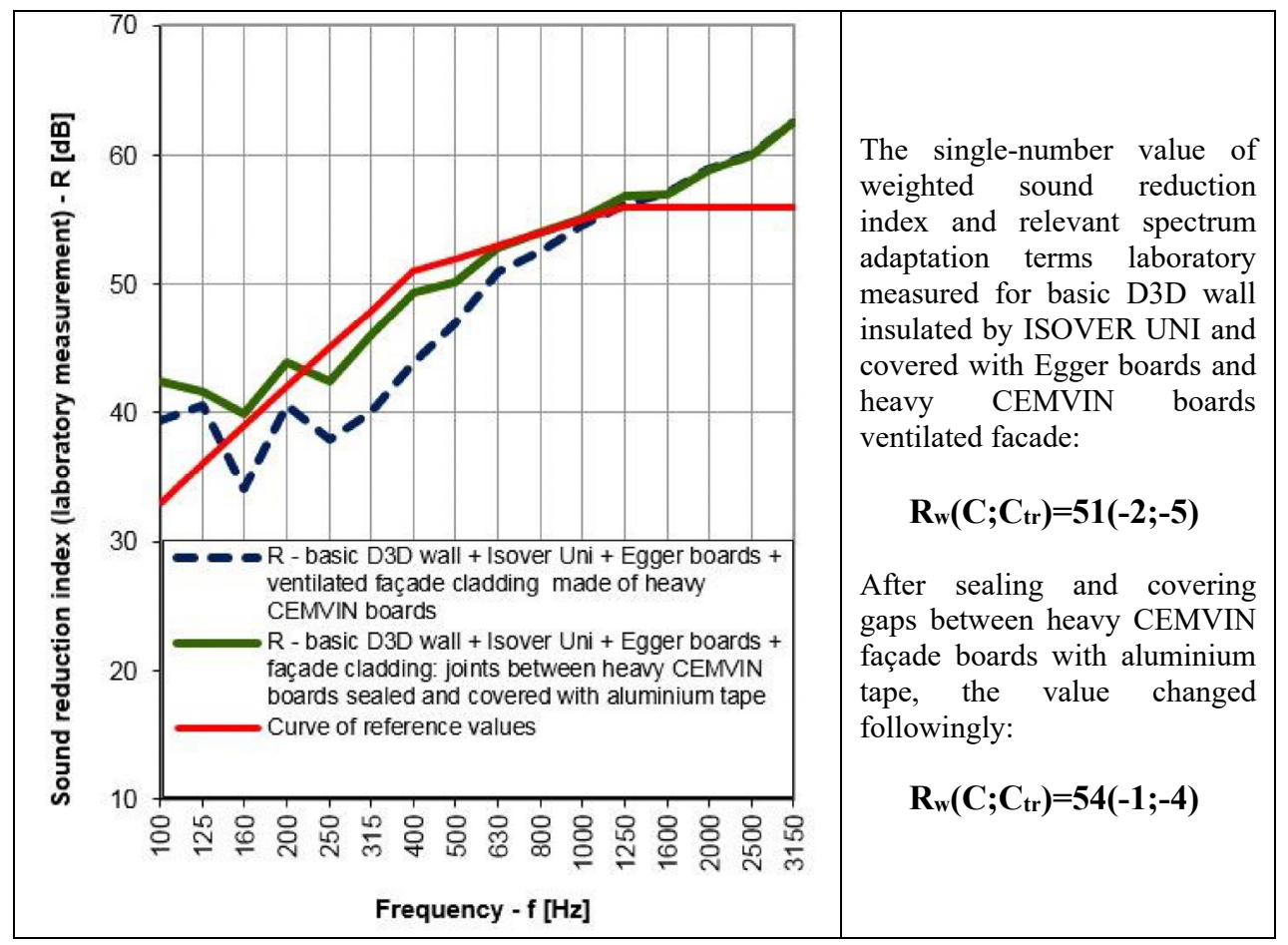

\section{Conclusions}

Generally, the massive glued laminated timber construction insulated with Steico Flex showed the single-number value of weighted sound reduction index by $1 \mathrm{~dB}$ lower than the construction insulated with ISOVER UNI. Both constructions showed a significant improvement of laboratory sound insulation at all measured frequencies, compared to uninsulated constructions. This phenomenon has been previously described by the authors for example in [5].

It is important to mention that for structures described in this article, precise insulation execution has a fundamental influence on sound insulation properties. No major leaks or errors are allowed in the sample envelope wall.

Focused on the influence of external ventilated façade with free gaps, i.e. free joints between façade boards, the benefit of such construction is approx. $0-1 \mathrm{~dB}$ of the total laboratory sound insulation value, while the uncertainty is approx. $2 \mathrm{~dB}$. Therefore, ventilated façade made of heavy façade boards has no unequivocal influence on the $\mathrm{R}_{W}$ value. The influence on the curve of sound reduction index $\mathrm{R}$ is apparent in the graphs. Nevertheless, the opinion that ventilated façade improves the sound insulation is still widespread among designers and builders. Consequently, faulty design leads to envelope wall defects.

After sealing and covering the gaps between façade boards with aluminium tape, the $\mathrm{R}_{\mathrm{W}}$ value increased by $3 \mathrm{~dB}$. Thus, if the gaps were covered, for example by different board installation method, the resulting construction could exhibit better sound insulation properties. Unfortunately, the ventilated façade needs vent inlets and outlets for proper function that act as acoustic weak point. 
For a completely correct assessment of individual influences on sound insulation properties, more sample walls and an extensive data set would be necessary.

This article was created thanks to cooperation of the Research Institute for Building Materials and the Faculties of Civil and Mechanical Engineering of the Brno University of Technology, concretely internal project 134624-RO-10/2013 and Project of University specific research FAST-S-16-3345 "Verification of behaviour and development of structures and structural elements and combined structures from wood and reinforced concrete, Faculty of Civil Engineering, Brno University of Technology.

Let us thank especially to Doc. RNDr. Marie Vaňková, CSc., RNDr. Anna Ryndová, Ph.D. and Doc RNDr. Miroslav Doložilek, CSc., for assistance with realization of the measurement - complete information on measurement are included in [6].

\section{References}

1. ČSN 73 0532, Acoustics - Protection against noise in buildings and evaluation of acoustic properties of building elements - Requirements (Czech Office for Standards, Metrology and Testing, 2010)

2. ČSN EN ISO 140-5. Acoustics - Measurement of sound insulation in buildings and of building elements - Part 5: Field measurement of airborne sound insulation of façade elements and façades (Czech Office for Standards, Metrology and Testing, 2010)

3. Z. Fišarová, L. Kalousek, Akustika 22, 12-19 (2014)

4. P. Valenta, Utility model no. 15073 U1, ČESKÉ DŘEVAŘSKÉ ZÁVODY PRAHA, A. S., PRAHA, CZ, Obvodový plášt' zateplené budovy (External cladding of thermalinsulated building), available on http:/www.upv.cz/cs/sluzby-uradu/databaze-online/databaze-patentu-a-uzitnych-vzoru.html

5. Z. Fišarová, L. Kalousek, M. Frank, Akustika 24, 16-24 (2015)

6. Protocol no. 35-2013 titled "Measurement of Laboratory Airborne Sound Insulation of external walls", issued by Acoustic Laboratory of the Institute of Physical Engineering, accredited as ĊIA, No. 1016. (2013) 